Received 30.09.2015 Reviewed 04.11 .2015 Accepted 23.11.2015

A - study design

B - data collection

C - statistical analysis

D - data interpretation

$\mathbf{E}$ - manuscript preparation

F - literature search

\section{Long-term air temperature and precipitation variability in the Warta River catchment area}

\author{
Piotr ILNICKI ${ }^{1)}$ ABCDEF, Ryszard FARAT ${ }^{2) ~ B C D E F}$, \\ Krzysztof GÓRECKI ${ }^{1) B C D E F}$, Piotr LEWANDOWSKI ${ }^{1) ~ B C D E F}$
}

\footnotetext{
${ }^{1)}$ Poznań University of Life Sciences, Department of Environmental Protection, Dąbrowskiego 159, 60-594 Poznań, Poland; e-mail: ilnickip@up.poznan.pl; goral@up.poznan.pl,piotrlew@up.poznan.pl

${ }^{2)}$ Institute of Meteorology and Water Management, Dąbrowskiego 174/176, 60-594 Poznań, Poland; e-mail: ryszard.farat@imgw.pl
}

For citation: Ilnicki P., Farat R., Górecki K., Lewandowski P. 2015. Long-term air temperature and precipitation variability in the Warta River catchment area. Journal of Water and Land Development. No. 27 p. 3-13.

\begin{abstract}
The variability of the mean annual air temperature and precipitation totals in three periods: 1848-2010, 1951-2010 and 1981-2010 was investigated in the large Warta River basin, being the area with lowest rainfall in Poland. For the purposes of research, nine meteorological stations with the longest measurement series were selected. Air temperature increase in this river basin was similar than in neighbouring countries. In the last 30 years this trend kept increasing. The precipitation in the whole studied period was slightly increasing in the northern part of the Warta River basin, but decreasing in the southern part. The mean annual precipitation totals in the catchment area did not change visible. In the period 1981-2010, the precipitation totals show a small increase in the winter and spring and a decrease in summer. A negative influence of this climate change was not visible in the Warta River discharge. The main objectives of this study were the collection long-term records of air temperature and precipitation in the Warta River basin, and the statistical analysis of climate variability.
\end{abstract}

Key words: precipitation totals, air temperature, trend analysis, Poland, Warta River basin

\section{INTRODUCTION}

In Europe after a slight period of coolness from the middle of the 19th century to about 1890 , a statistically significant warming occurred from 1890 to 1950 (by $0.15^{\circ} \mathrm{C}$ per decade). Then, there followed a cooling from 1950 to 1970 and again a slight warming from the early 1970s [BALLING et al. 1998]. The European Climate Assessment data set comprises about 200 series of temperatures and precipitations from nearly all European countries and shows that in the period 1976-1999, the temperature trends were positive all over Europe and the strongest warming was visible in winter. Apart from the north-south gradient [TRENBERTH et al. 2007], there was a weaker gradient from the ocean to the continent. The highest temperature rises were found over central and north-eastern Europe, while the lowest over the Mediterranean. The spatial coherence of precipitation and their trends were generally lower due to their inherent higher variability [KLEIN TANK et al. 2002].

In most European investigations the number of Polish station was very small and the analysed series changed from 1961-2004 [SCHERRER et al. 2005] to 1901-1999 [KLEIN TANK et al. 2005], 1911-2000 [JONES, LISTER 2009] and 1753-2011 [ROHDE et al. 2013]. Long-term European temperature research in 1751-1995 used only two Polish meteorological stations [BALLING et al. 1998] and reconstruction of records 1500-2007 for Central Europe used no one Polish station records after 1760 [DOBROVOLNÝ et al. 2010]. This shows a large lack of meteorological data 
used in European investigations from the Polish territories.

Air temperature and precipitation long-term series were studied in different periods in most European countries, but not in catchment areas. From the Polish point of view, of particular interest are the results from neighbouring countries. The mean temperature series for the Czech Republic showed in the period $1848-2000$, a statistically significant positive linear trend, which reached $0.69^{\circ} \mathrm{C}$ per 100 years. An insignificant trend towards precipitation rise was evident in winter and in autumn [BRÁZDIL et al. 2009]. In Germany the trends of temperature and precipitation were studied for the period 1901-2000 and 19712000 , where the temperature rise was about $0.7^{\circ} \mathrm{C}$ and $0.3^{\circ} \mathrm{C}$ respectively. In Germany, the trends increased from the north to the south, though weakened from east to west. The areally averaged annual precipitation total increased in Germany for the period 1901-2004 from $735 \mathrm{~mm}$ to $800 \mathrm{~mm}$, mainly in winter [SCHÖNWIESE, JANOSCHITZ 2008]. Between 1951-1988 and 1989-2008, the average annual temperature in the flat part of Ukraine increased by $0.8^{\circ} \mathrm{C}$. The highest increase was recorded in winter (January) and in spring (March). The annual precipitation totals in that time did not change significantly, while the change was most significant in spring (March) and autumn [NABYVANETS et al. 2011].

In central Poland long-term meteorological records exist only for Bydgoszcz, Poznań, the Leszno region [HOHENDORF 1966; SMOSARSKI 1925] and Łódź [WIBIG et al. 2004; WIBIG, RZEPA 2007]. Longer was time series in Warsaw, Wrocław and Brno [BRÁZDIL et al. 2009]. In Warsaw in the period 17791998 the air temperature trend was $0.055^{\circ} \mathrm{C}$ per decade [LORENC 2000] and in Wrocław, in 1791-2007, it was higher $\left(0.085^{\circ} \mathrm{C}\right.$ per decade) [BRYŚ, BRYŚ 2010]. In Poznan in the period 1848-1922 the mean temperature was $0.9^{\circ} \mathrm{C}$ lower than for $1960-2009$, while for 2000-2009 it was much as $1.9^{\circ} \mathrm{C}$ higher [NYĆKOWIAK et al. 2014]. For the period 1951-2000 in Poland the trend was significant and positive in the annual temperature $\left(0.2^{\circ} \mathrm{C}\right.$ per decade), and in March and April. During this period there was a weak, insignificant increasing trend in the annual precipitation totals, but significant only in March and the precipitation decreased mainly between June and August [DEGIRMENDŽIĆ et al. 2004]. The variability of the thermal and precipitation conditions in Poland in the second half of the 20th century show a significant increase of temperature in the spring and winter, but the amount of precipitation total does not show any significant trend [ŻMUDZKA 2004]. The myth of the steppe forming process in the Wielkopolska region from the viewpoint of long investigations of water circulations was presented by ILNICKI et al. [2012].

The main objectives of this study were the collection of all published and unpublished, long-term records of air temperature and precipitation in the Warta River basin, boasting the lowest annual rainfall in
Poland, and the statistical analysis of climate variability. Data for this region was not available and used in most European climatic investigations. In the 18482010, 1951-2010 and 1981-2010 periods the trend of this most important climate parameters were calculated and analysed. The climatic variability in the Warta River basin has been compared with the numerous results of similar studies carried out mainly in Central Europe, to ascertain the differences of climate change in the region and their influence on water management, environment and agriculture production.

\section{DATA AND METHODOLOGY}

Climatic changes include the variability of the hydrological cycle and water resources, connected with precipitation and air temperature. Therefore it is logical when climatic changes are studied not in terms of administrative units, but in river basins. We analysed the Warta River basin $\left(54519 \mathrm{~km}^{2}\right)$ which in the period 1896-2010 showed a mean annual specific run-off amounting only to $3.86 \mathrm{dm}^{3} \cdot \mathrm{s}^{-1} \mathrm{~km}^{-2}$ [ILNICKI et al. 2014]. In Poland it is the basin with the lowest precipitation totals, being a region potentially threatened by an intensive drought, especially through increasing air temperature.

In the Warta River basin nine meteorological stations with long-time series of air temperatures and precipitations were analysed (Fig. 1). The observations started in 1848 in Bydgoszcz, Poznań and the region of Leszno (Czechnów, Góra, Wschowa), in the

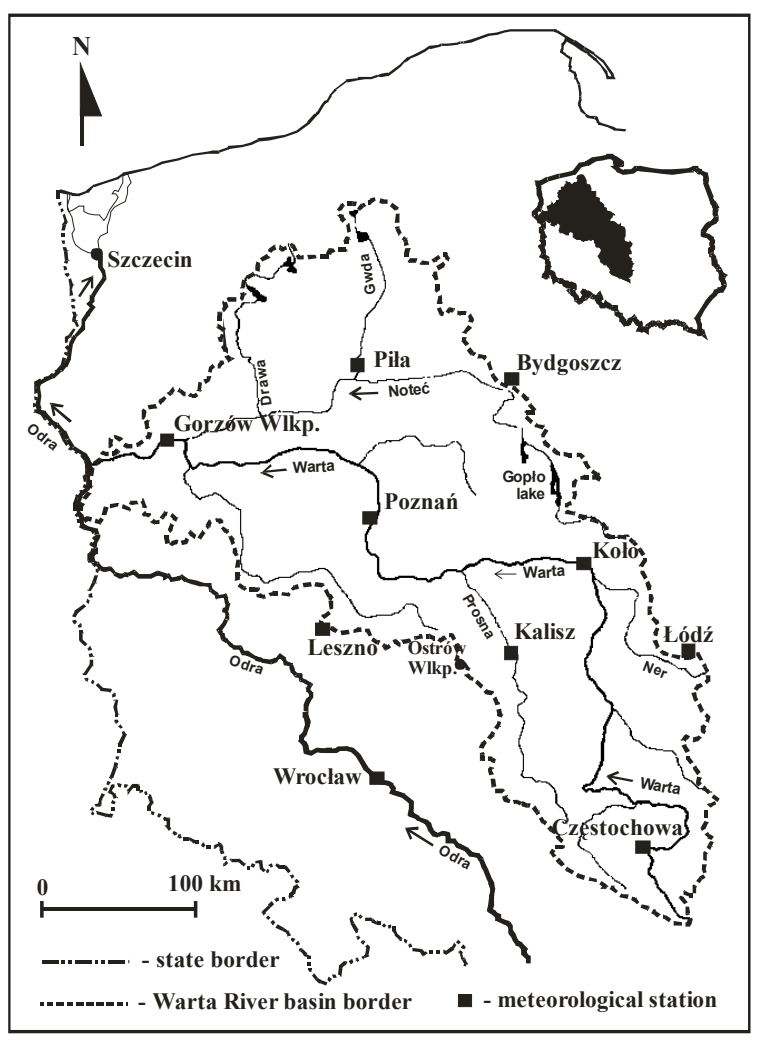

Fig. 1. The Warta River basin - location of meteorological stations; source: own elaboration 
1890s in Częstochowa, Gorzów Wlkp., Kalisz (Ostrów Wlkp.) and Piła (Wałcz) region; in 1903, in Łódź and in 1931, in Koło. Through this, in Central Europe an evaluation of the meteorological stations was realized progressive; the mean values of temperature and precipitation in the river basin could be calculated at first only for three and seven stations respectively, and from 1931 for nine.

The stations in Bydgoszcz, Czechnów, Góra, Leszno, Ostrów Wlkp. and Poznań had been established and originally they conducted observations in schools. Later, that function was taken over by the Prussian and German meteorological offices until 1918, whereas in Gorzów Wlkp., Wałcz and Wschowa as late as 1945. The stations in Częstochowa, Kalisz and Łódź were organized and observed by the Russian authorities until 1918. That same year and again in 1945 the state borders in this region changed and consequently all the stations were taken over by the Polish State Institute of Hydrology and Meteorology (PIHM) and later, the Institute of Meteorology and Water Management (IMGW). Throughout these political changes and station relocations, to create mean values for the Warta River basin for Leszno and to a lesser extent for Kalisz and Piła, we used the data from stations located nearby (less than $20 \mathrm{~km}$ ), which had been earlier established in that flat and rural region. The characteristics of stations inform about their relocations in the period 1848-2010 (Tab. 1). The stations in the most towns were located in the outlying suburbs. Differences in the terrain height of subsequent stations are the greatest (about $30 \mathrm{~m}$ ) in Częstochowa, lying on the highland and in Gorzów Wlkp. and Kalisz, situated near deep river valleys. However, the differences were not very great. In 1972, only Łódź and Poznań had over 500000 inhabitants, while the bigger towns included Bydgoszcz (280 000) and Częstochowa (190 000 inhabitants). The remaining stations were located in towns counting at that time about 30-80 thousand inhabitants. An analysis of the impact of station relocation on the mean annual air temperature did not show any unexpected changes.

Table 1. Characteristics of meteorological stations and their relocations in the Warta River basin

\begin{tabular}{|c|c|c|c|c|c|c|c|}
\hline \multirow{2}{*}{ Station } & \multirow{2}{*}{$\begin{array}{l}\text { Code } \\
\text { WMO }\end{array}$} & \multirow{2}{*}{$\begin{array}{l}\text { Neighbouring station } \\
\text { and relocations }\end{array}$} & \multirow{2}{*}{$\begin{array}{c}\text { Elevation } \\
\text { m a.s.1. }\end{array}$} & \multicolumn{2}{|c|}{ Coordinates } & \multicolumn{2}{|c|}{ Period examined } \\
\hline & & & & latitude $\mathrm{N}$ & longitude $\mathrm{E}$ & air temperature & precipitation \\
\hline \multirow{3}{*}{ Bydgoszcz } & \multirow{3}{*}{240} & Bydgoszcz & 46 & $53^{\circ} 08^{\prime}$ & $18^{\circ} 00^{\prime}$ & $1848-1897$ & $1861-1897$ \\
\hline & & Agricultural School & 46 & $53^{\circ} 08^{\prime}$ & $18^{\circ} 00^{\prime}$ & 1897-1908 & $1897-1908$ \\
\hline & & Agricultural Institute & 70 & $53^{\circ} 08^{\prime}$ & $17^{\circ} 58^{\prime}$ & $1905-2010$ & $1905-2010$ \\
\hline \multirow{2}{*}{ Częstochowa } & \multirow{2}{*}{550} & Częstochowa & 259 & $50^{\circ} 49^{\prime}$ & $19^{\circ} 09^{\prime}$ & 1921-1939 & 1891-1939 \\
\hline & & Częstochowa, airport & 293 & $50^{\circ} 49^{\prime}$ & $19^{\circ} 05^{\prime}$ & 1939-2010 & 1939-2010 \\
\hline \multirow{4}{*}{ Gorzów Wlkp. } & \multirow{4}{*}{300} & Gorzów Wlkp. & 70 & $52^{\circ} 44^{\prime}$ & $15^{\circ} 14^{\prime}$ & 1891-1945 & $1875-1945$ \\
\hline & & Gorzów Wlkp. & 44 & $52^{\circ} 44^{\prime}$ & $15^{\circ} 15^{\prime}$ & $1946-1954$ & 1946-1954 \\
\hline & & Gorzów Wlkp. & 67 & $52^{\circ} 44^{\prime}$ & $15^{\circ} 15^{\prime}$ & $1954-1974$ & 1954-1974 \\
\hline & & Gorzów Wlkp. & 73 & $52^{\circ} 44^{\prime}$ & $15^{\circ} 16^{\prime}$ & $1974-2010$ & $1974-2010$ \\
\hline \multirow{4}{*}{ Kalisz } & \multirow{4}{*}{435} & Ostrów Wlkp. & 143 & $51^{\circ} 39^{\prime}$ & $17^{\circ} 49^{\prime}$ & $1891-1920$ & - \\
\hline & & Kalisz & 109 & $51^{\circ} 46^{\prime}$ & $18^{\circ} 06^{\prime}$ & $1921-1945$ & $1921-1945$ \\
\hline & & Kalisz, railway station & 140 & $51^{\circ} 44^{\prime}$ & $18^{\circ} 05^{\prime}$ & $1945-1985$ & $1945-1985$ \\
\hline & & Kalisz, Majków & 138 & $51^{\circ} 47^{\prime}$ & $18^{\circ} 05^{\prime}$ & $1985-2010$ & $1985-2010$ \\
\hline \multirow{2}{*}{ Koło } & \multirow{2}{*}{345} & Koło & 97 & $52^{\circ} 12^{\prime}$ & $18^{\circ} 38^{\prime}$ & 1931-1968 & $1931-1968$ \\
\hline & & Koło & 116 & $52^{\circ} 12^{\prime}$ & $18^{\circ} 40^{\prime}$ & 1968-2010 & $1968-2010$ \\
\hline \multirow{5}{*}{ Leszno } & \multirow{5}{*}{418} & Czechnów & 102 & $51^{\circ} 40^{\prime}$ & $16^{\circ} 42^{\prime}$ & $1848-1871$ & $1848-1871$ \\
\hline & & Góra & 87 & $51^{\circ} 40^{\prime}$ & $16^{\circ} 33^{\prime}$ & $1871-1882$ & $1871-1882$ \\
\hline & & Wschowa & 102 & $51^{\circ} 48^{\prime}$ & $16^{\circ} 19^{\prime}$ & $1883-1918$ & $1883-1918$ \\
\hline & & Leszno, Antoniny & 93 & $51^{\circ} 50^{\prime}$ & $16^{\circ} 32^{\prime}$ & 1919-1960 & $1919-1960$ \\
\hline & & Strzyżewice, airport & 91 & $51^{\circ} 50^{\prime}$ & $16^{\circ} 32^{\prime}$ & $1957-2010$ & $1957-2010$ \\
\hline \multirow{2}{*}{ Łódź } & \multirow{2}{*}{465} & Tramway depot, city & 208 & $51^{\circ} 46^{\prime}$ & $19^{\circ} 29^{\prime}$ & $1921-1930$ & $1904-1930$ \\
\hline & & Lublinek, airport & 187 & $51^{\circ} 43^{\prime}$ & $19^{\circ} 24^{\prime}$ & 1931-2010 & 1931-2010 \\
\hline \multirow{2}{*}{ Piła } & \multirow{2}{*}{230} & Wałcz & 118 & $53^{\circ} 17^{\prime}$ & $16^{\circ} 28^{\prime}$ & 1891-1969 & $1883-1909$ \\
\hline & & Piła & 73 & $53^{\circ} 08^{\prime}$ & $16^{\circ} 45^{\prime}$ & 1970-2010 & $1910-2010$ \\
\hline \multirow{3}{*}{ Poznań } & \multirow{3}{*}{330} & Zielona street & 80 & $52^{\circ} 25^{\prime}$ & $16^{\circ} 56^{\prime}$ & $1848-1910$ & $1848-1910$ \\
\hline & & University, Coll. Min. & 78 & $52^{\circ} 25^{\prime}$ & $16^{\circ} 54^{\prime}$ & 1911-1935 & $1911-1935$ \\
\hline & & Ławica, airport & 83 & $52^{\circ} 25^{\prime}$ & $16^{\circ} 50^{\prime}$ & $1924-2010$ & $1924-2010$ \\
\hline
\end{tabular}

Source: own study.

Used data are part of the quality controlled data base in the Institute of Meteorology and Water Management (IMGW), some of them were published. Their quality control included detection, verification and possible correction of outliers, elimination of wrong values and addition of missing data in the time series. In Poland in the analysed time, there were no significant changes in equipment facilities, or in ob- servation principles. An automation of stations was carried out at the turn of the 20th and 21 st centuries. However, changes in observation terms and averaging methods occurred without any great differences in the data obtained. Monthly data of air temperature and rainfall for every year were available only for Bydgoszcz (rainfall from 1861), Leszno and Poznań in 1848-2010 and for all stations in 1981-2010. For the 
periods 1881-1930, 1931-1950 and 1951-1980 for the remaining six stations, only the mean monthly data for periods of air temperature were available, not the monthly data in every year. Similarly in the case of precipitations, but these periods were different in the 19th century $(1848-1860,1861-1890$ and $1891-$ 1930). We analysed the variability of air temperature and precipitation totals in terms of years and four seasons. Annual air temperature and precipitation totals were collected for all years and all stations, and used for trend calculations. Mean values of air temperature and precipitation for the whole Warta catchment were calculated as the mean values from all nine analysed stations.

The coefficient of variation was used for describing the variability of air temperature and precipitation totals, as well as standard air temperature deviation. Because it is not certain that these two parameters have a normal distribution, for the calculation of trend values, we used linear regression and the non-parametric Mann-Kendall test with the aid of Hydrospect software, version 2.0 [RADZIEJEWSKI, KUNDZEWICZ 2000; 2004]. The calculations were completed for nine meteorological stations and with their mean annual values for the whole Warta River basin. We presented trends for air temperature and precipitation totals in the whole basin for three periods: 18482010, 1951-2010 and 1981-2010 and for all meteorological stations in their longest periods. The $p$-values are calculated for the trend values (slopes) and by linear regression for correlation coefficients. This makes possible a comparison between the longest analysed periods and the last two periods in which global climate change was observed. Data for periods mentioned were compared with the variability of the Warta River discharge in the 20th century. The correlation existing in the series of the mean annual temperatures and the precipitation totals between the particular stations is regarded as good and very good accordingly when the value of the correlation coefficient shows $r>0.7$, or $r>0.9$ respectively [SCHÖNWIESE, JANOSCHITZ 2008]. In air temperature, these values from nine stations were mainly in the interval of $0.87-0.98$, while in reference to precipitation, the values were significantly lower $(0.54-0.63)$. For a pair of closely situated stations, the correlation coefficient for precipitation range was found to be within $0.60-0.74$. Low values of the correlation coefficient in precipitation result from a significantly higher spatial variability. The above calculations indicate that the density of the stations studied is representative for Warta River basin research.

\section{RESULTS}

\section{AIR TEMPERATURE CHANGES IN THE PERIOD 1848-2010}

In the Warta River basin in the longest time-series (1848-2010) the mean annual air temperature was $8.1^{\circ} \mathrm{C}$. It increased in $1951-2010$ to $8.2^{\circ} \mathrm{C}$, and in the last 30 years $(1981-2010)$ to $8.6^{\circ} \mathrm{C}$ (Tab. 2). In the north (Bydgoszcz, Piła) and south-east part (Częstochowa, Łódź) of the catchment area the mean annual air temperature was slightly lower $\left(7.8-7.9^{\circ} \mathrm{C}\right)$. The 10 -year moving average air temperature for all meteorological stations (Fig. 2) and for the river basin showed periods of higher and lower temperature, with the lowest annual means in 1954-1980, and the highest ones in 1857-1869, 1913-1921, 1931-1950 and especially in 1988-2009 (Fig. 3). These periods do not alternate cyclically. The linear trend of the mean annual air temperature in all analysed stations and in three periods in the total Warta River basin was positive and significant. For shorter time periods in stations it increased slightly (Tab. 3) but in the river basin in three periods it was quite different. In the relevant base of 163 years the linear trend of temperature differences was only $0.039^{\circ} \mathrm{C} / 10$ years. In the period $1951-2010$ this trend was much higher $\left(0.232^{\circ} \mathrm{C} / 10\right.$ years) through the long cold period 1954-1980. In the last 30 -years period the trend was very high $\left(0.351^{\circ} \mathrm{C} / 10\right.$ years $)$ - through the volcano eruption in Iceland in 2010 decreased the annual air temperature

Table 2. Statistical analyses of annual mean air temperature $\left({ }^{\circ} \mathrm{C}\right)$ variability in the Warta River basin

\begin{tabular}{|c|c|c|c|c|c|c|}
\hline Meteorological station & Period & $\begin{array}{c}\text { Annual mean air } \\
\text { temperature } \\
{ }^{\circ} \mathrm{C}\end{array}$ & $\begin{array}{l}\text { Coefficient of } \\
\text { variation }\end{array}$ & $\begin{array}{l}\text { Standard } \\
\text { deviation }\end{array}$ & $\begin{array}{l}\text { Linear trend } \\
{ }^{\circ} \mathrm{C} \text { per decade }\end{array}$ & $\begin{array}{c}\text { Mann-Kendall's } \\
\text { statistics** }\end{array}$ \\
\hline Bydgoszcz & \multirow{3}{*}{$1848-2010$} & 7.8 & 0.107 & 0.84 & $0.042 *$ & 2.98 \\
\hline Leszno & & 8.3 & 0.101 & 0.84 & $0.035 *$ & 2.53 \\
\hline Poznań & & 8.3 & 0.101 & 0.84 & $0.046^{*}$ & 3.26 \\
\hline Gorzów Wlkp. & \multirow{3}{*}{$1891-2010$} & 8.3 & 0.102 & 0.85 & $0.099 *$ & 4.44 \\
\hline Kalisz & & 8.3 & 0.104 & 0.86 & $0.063 *$ & 2.88 \\
\hline Piła & & 7.8 & 0.109 & 0.85 & $0.075 *$ & 3.55 \\
\hline Częstochowa & \multirow{2}{*}{$1921-2010$} & 7.9 & 0.112 & 0.89 & $0.094 *$ & 2.36 \\
\hline Łódź & & 7.9 & 0.110 & 0.87 & $0.102 *$ & 3.55 \\
\hline Koło & $1931-2010$ & 8.2 & 0.109 & 0.90 & $0.096^{*}$ & 2.07 \\
\hline \multirow{3}{*}{$\begin{array}{l}\text { The Warta River basin } \\
\text { ( } 9 \text { stations) }\end{array}$} & $1848-2010$ & 8.1 & 0.102 & 0.82 & $0.040 *$ & 2.79 \\
\hline & $1951-2010$ & 8.2 & 0.106 & 0.87 & $0.232 *$ & 3.60 \\
\hline & $1981-2010$ & 8.6 & 0.100 & 0.85 & $0.351 *$ & 2.15 \\
\hline
\end{tabular}

Explanations: *significant at the 0.05 level, ** the trend is statistically significant if the test statistic is higher than 2. Source: own study. 

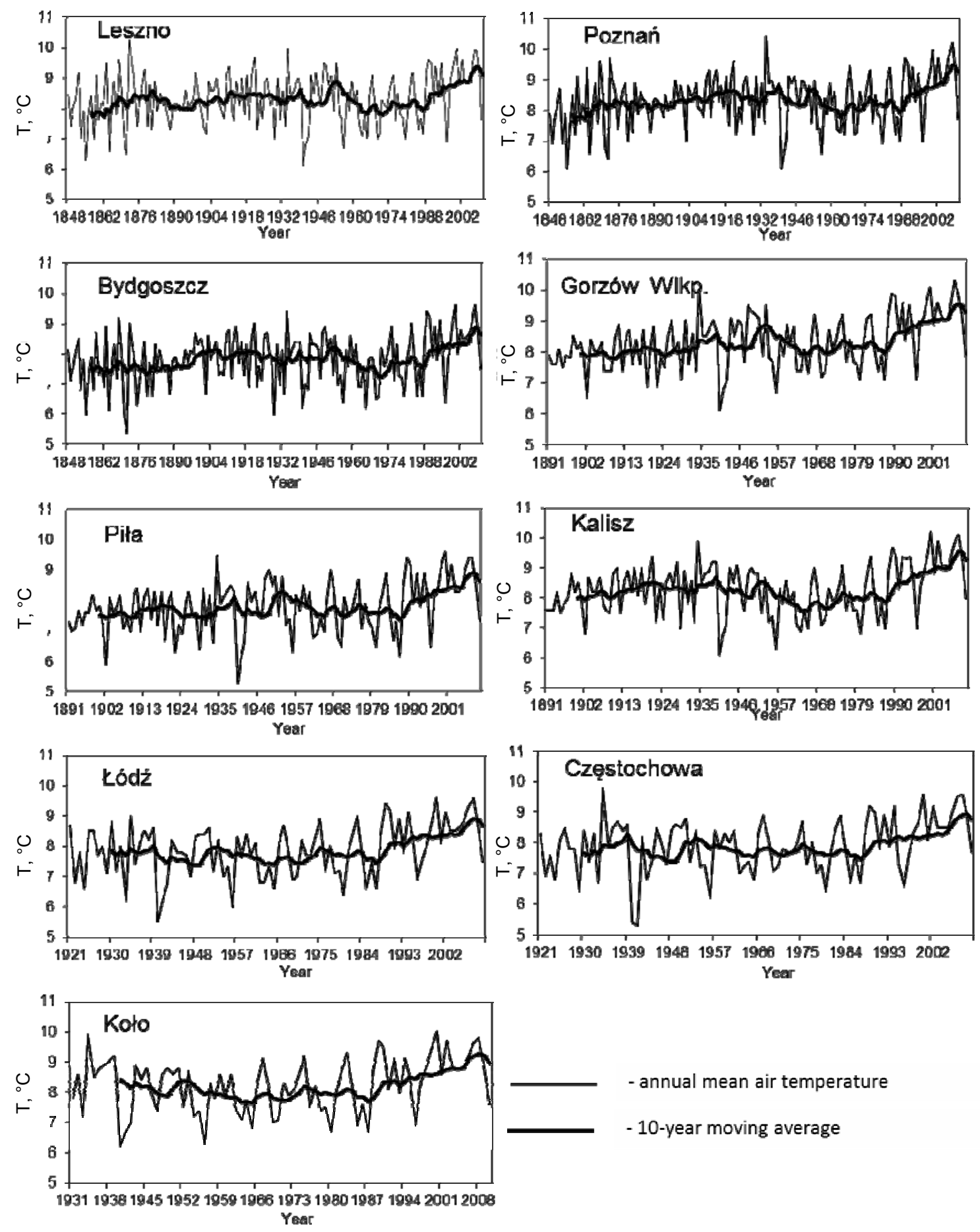

Fig. 2. Long term variability of mean annual and 10-year moving average air temperature $\left({ }^{\circ} \mathrm{C}\right)$ in Leszno, Poznań, Bydgoszcz, Gorzów Wlkp. Piła, Kalisz, Łódź, Częstochowa and Koło in 1848-2010; source: own study

in the Warta River basin to $7.6^{\circ} \mathrm{C}$. In the Warta River basin the increase of air temperature in the period 1981-2010 (Tab. 3) was most visible in spring (March-May) and winter (December-February). The trend was positive and significant $\left(0.63^{\circ} \mathrm{C} / 10\right.$ years $)$ only in spring (Fig. 4). In other seasons, it was positive, mostly in winter, but not in autumn. This indicates a gradual increase of spring and winter air temperature, one that subsequently generates slow snow cover persistence and higher water infiltration into the soil.

\section{PRECIPITATION CHANGES IN THE PERIOD 1848-2010}

In the Warta River basin (Tab. 4) in all three analysed time series $(163,60$ and 30 years) the mean annual precipitation totals were very similar $(548,547$ and $544 \mathrm{~mm})$. In eight stations this mean fluctuated only between $510.5 \mathrm{~mm}$ in Poznań to $578.6 \mathrm{~mm}$ in Łódź. It was higher $(648.6 \mathrm{~mm})$ only in the upper part of the river basin (Częstochowa). The lowest annual 


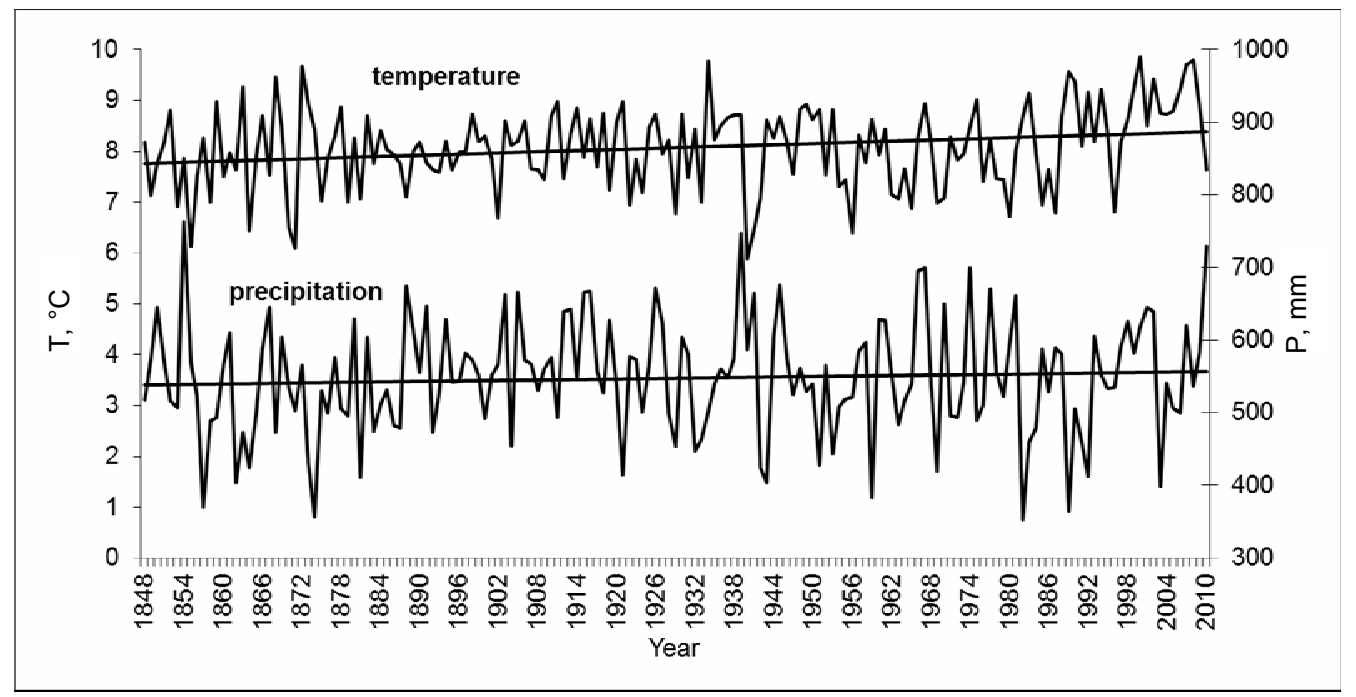

Fig. 3. Trend of annual mean air temperature $\left({ }^{\circ} \mathrm{C}\right)$ and precipitation totals $(\mathrm{mm})$ in the Warta River basin in the period 1848-2010; source: own study

Table 3. Mean air temperature and precipitation totals in the Warta River basin in seasons and various periods

\begin{tabular}{|c|c|c|c|c|c|c|c|c|c|c|}
\hline \multirow{3}{*}{ Period } & \multicolumn{5}{|c|}{ Air temperature } & \multicolumn{5}{|c|}{ Precipitation totals } \\
\hline & \multirow{2}{*}{$\begin{array}{c}\text { annual } \\
{ }^{\circ} \mathrm{C}\end{array}$} & \multicolumn{4}{|c|}{ mean in season, ${ }^{\circ} \mathrm{C}$} & \multirow{2}{*}{$\begin{array}{c}\text { annual } \\
\mathrm{mm}\end{array}$} & \multicolumn{4}{|c|}{ mean in season, \% } \\
\hline & & $\begin{array}{l}\text { spring } \\
\text { MAM }\end{array}$ & $\begin{array}{c}\text { summer } \\
\text { JJA }\end{array}$ & $\begin{array}{c}\text { autumn } \\
\text { SON }\end{array}$ & $\begin{array}{c}\text { winter } \\
\text { DJF }\end{array}$ & & $\begin{array}{l}\text { spring } \\
\text { MAM }\end{array}$ & $\begin{array}{c}\text { summer } \\
\text { JJA }\end{array}$ & $\begin{array}{c}\text { autumn } \\
\text { SON }\end{array}$ & $\begin{array}{l}\text { winter } \\
\text { DJF }\end{array}$ \\
\hline A $1848-2010$ & 8.1 & 7.7 & 17.5 & 8.3 & -1.2 & 548 & 21.9 & 37.9 & 22.0 & 18.2 \\
\hline B 1951-2010 & 8.2 & 7.9 & 17.4 & 8.5 & -1.0 & 547 & 22.0 & 37.8 & 22.2 & 18.0 \\
\hline C 1981-2010 & 8.6 & 8.5 & 17.7 & 8.6 & -0.6 & 544 & 22.8 & 36.4 & 22.0 & 18.8 \\
\hline Difference B-A & 0.1 & 0.2 & -0.1 & 0.2 & 0.2 & 1 & 0.1 & -0.1 & 0.2 & -0.2 \\
\hline Difference $\mathrm{C}-\mathrm{A}$ & 0.5 & 0.8 & 0.3 & 0.1 & 0.6 & 4 & 0.9 & -1.5 & 0.0 & 0.6 \\
\hline
\end{tabular}

Explanations: MAM = March, April, May, JJA = June, July, August, SON $=$ September. October, November, DJF $=$ December, January, February.

Source: own study.
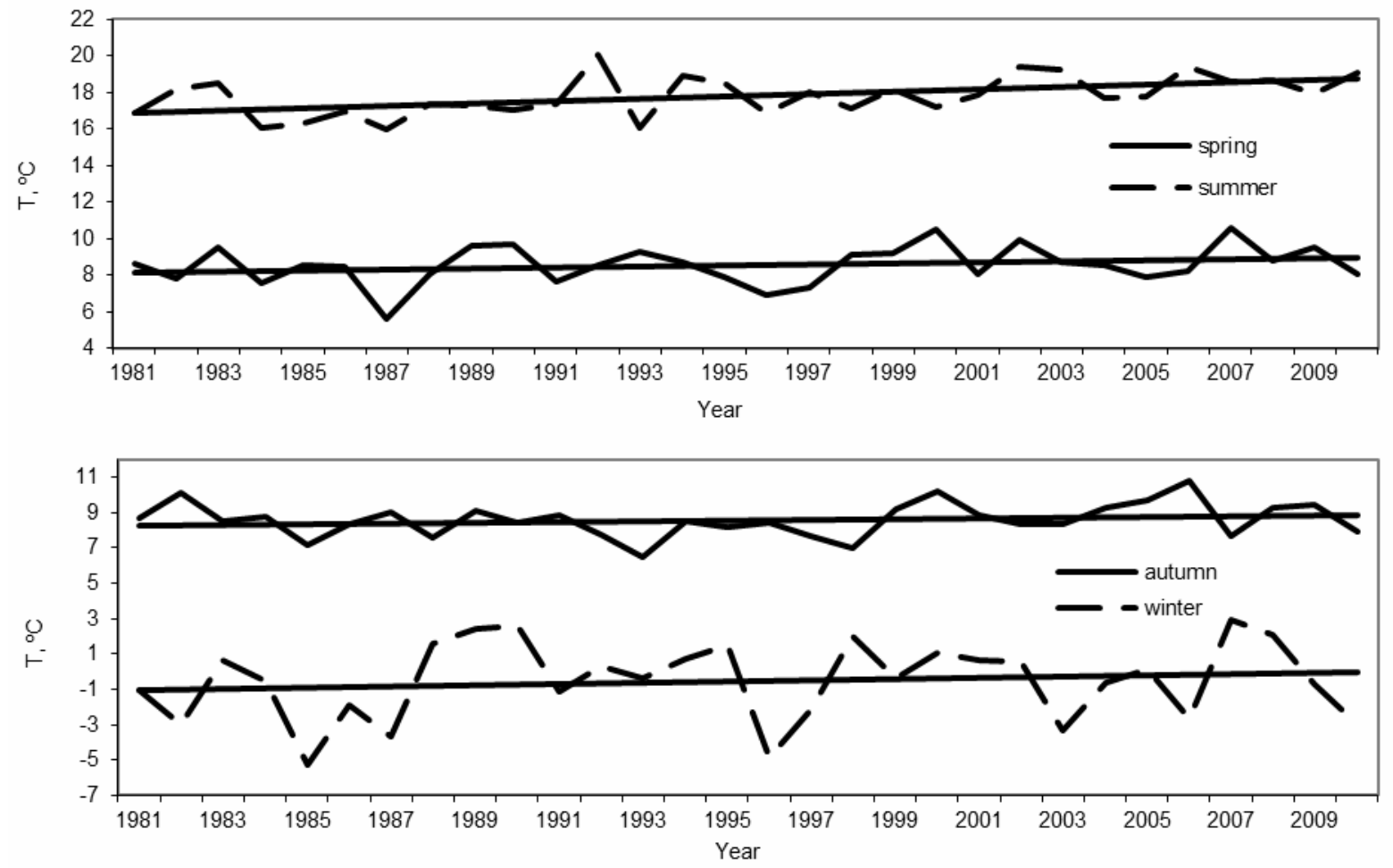

Fig. 4. Variability of the mean air temperatures $\left({ }^{\circ} \mathrm{C}\right)$ in four seasons in the Warta River basin in 1981-2010; source: own study 
Table 4. Statistical analyses of annual precipitation totals $(\mathrm{mm})$ variability in the Warta River basin

\begin{tabular}{|l|c|c|c|c|c|}
\hline \multicolumn{1}{|c|}{ Meteorological station } & Period & $\begin{array}{c}\text { Annual mean } \\
\text { precipitation totals } \\
\mathrm{mm}\end{array}$ & $\begin{array}{c}\text { Coefficient } \\
\text { of variations }\end{array}$ & $\begin{array}{c}\text { Linear trend* } \\
\text { mm per decade }\end{array}$ & $\begin{array}{c}\text { Mann-Kendall's } \\
\text { statistics** }\end{array}$ \\
\cline { 1 - 5 } Leszno & $1848-2010$ & 546 & 0.179 & -2.01 & -0.91 \\
\cline { 1 - 5 } Poznań & $1848-2010$ & 511 & 0.190 & 2.11 & 1.22 \\
\hline Bydgoszcz & $1861-2010$ & 517 & 0.187 & 1.51 & 0.91 \\
\hline Gorzów Wlkp. & $1875-2010$ & 552 & 0.176 & 0.12 & 0.62 \\
\hline Piła & $1883-2010$ & 561 & 0.181 & -0.48 & -0.02 \\
\hline Częstochowa & $1891-2010$ & 649 & 0.171 & -3.78 & -0.17 \\
\hline Łódź & $1904-2010$ & 579 & 0.174 & -1.25 & -1.65 \\
\hline Kalisz & $1921-2010$ & 524 & 0.193 & -7.66 & 1.45 \\
\hline Koło & $1931-2010$ & 523 & 0.180 & 5.24 & 1.06 \\
\hline $\begin{array}{l}\text { The Warta River basin } \\
\text { (9 stations) }\end{array}$ & $1848-2010$ & 548 & 0.146 & 1.10 & 1.10 \\
\cline { 2 - 5 } & $1951-2010$ & 547 & 0.156 & 5.95 & 1.87 \\
\cline { 2 - 5 } & $1981-2010$ & 544 & 0.164 & 34.6 & \\
\hline
\end{tabular}

Explanations: * trend is not significant at the 0.05 level; ** the trend is statistically significant if the test statistic is higher than 2 or lower than -2 .

Source: own study.

precipitation totals $(<450 \mathrm{~mm})$ were measured in the extremely dry years 1857-1865, 1951-1959 and 1982-1992. Fluctuations between succeeding years was often very high (Fig. 5). The linear trend of mean annual precipitation totals in the Warta River basin was small $(1.1 \mathrm{~mm} / 10$ years), positive but not significant. The same result was given according to MannKendall statistics. The small differences of annual precipitation in the longest periods in Koło, Poznan, Bydgoszcz and Gorzów Wlkp., situated in the northern and central part of the Warta River basin was positive, and negative in Kalisz, Częstochowa, Leszno, Łódź and Piła, situated in its southern and eastern part. The change in these stations was never statistically significant (Tab. 4) and the coefficient of variations was high. In the periods 1951-2010 and 19812010 the linear trend of the mean annual precipitation totals in the Warta River basin was higher and positive, but not statistically significant. In the last period the influence of extremely dry years in the period 1982-1992 was visible.

The highest share in seasons for this period of 163 years was in summer (37.9\%). It was very similar in spring and autumn and the lowest in winter. In the Warta River basin the share of precipitation totals in the seasons observed for three periods changed visibly only in 1981-2010 (Tab. 3). There was a slight rise in the percentage of precipitation in spring and winter and a decrease followed in summer. A very similar phenomenon was also observed for the period 18911930. In the period 1981-2010 the change was positive (Fig. 6) and the trend significant only in spring (13.6 $\mathrm{mm}$ per decade).

\section{DISCUSSION}

In the second half of the 20th century, the mean global temperature increased from 1956 to 2005 by $0.13^{\circ} \mathrm{C}$ per decade [TRENBERTH et al. 2007] and between $1950-2010$ by $0.14^{\circ} \mathrm{C}$ per decade [ROHDE et al. 2013]. The temperature series in the Northern Hemi- sphere showed a statistically significant linear trend of $0.24^{\circ} \mathrm{C}$ per decade for annual value in the period 1961-2005, with highest temperatures in winter and spring [BROHAN et al. 2006].

In the Baltic Sea region during in the period 1871-2013 the near surface temperatures showed continued warming, in particular during spring and winter and this has been shown to be stronger over northern regions. No long-term trends are detectable for precipitation, although some regional indications exist for an increased length of precipitation periods [RUTGERSSON et al. 2014].

In our longest time-series (1848-2010) in the Warta River basin the linear trend of mean annual air temperature $\left(0.04^{\circ} \mathrm{C}\right.$ per decade) was small, positive and statistically significant. In the period 1951-2010 in the Warta River basin the annual mean temperature increased by $0.23^{\circ} \mathrm{C}$ per decade. A similar trend $\left(0.20^{\circ} \mathrm{C}\right.$ per decade) occurred in $1951-2000$ in Poland [DEGIRMENDŽIĆ et al. 2004] and in Germany [SCHÖNWIESE, JANOSCHITZ 2008]. In a shorter period (1971-2000) the trend was higher in the Czech Republic (about $0.3^{\circ} \mathrm{C}$ per decade) [BRÁzDIL et al. 2009] and on the Germany-Poland border $\left(0.24-0.33^{\circ} \mathrm{C}\right.$ per decade) [SCHÖNWIESE, JANOSCHITZ 2008].

Because the climate change had a large impact on water management, our investigations were realized also in large river basins. Similar idea have given birth to investigations in the Yangtze River [ZHANG et al. 2014], as well as in the Betwa Basin in India [SURYAVAVANSHI et al. 2014].

In the period 1981-2010 in the Warta River basin the trend of air temperature was also higher $\left(0.35^{\circ} \mathrm{C}\right.$ per decade), but in Germany in the period 1971-2000 it was still $0.3^{\circ} \mathrm{C}$ per decade [SCHÖNWIESE, JANOSCHITZ 2008]. These data show that the comparison of air temperature trends in various regions without taking into consideration the relevant analysed periods will not produce the correct results.

In the Warta River basin, for the period 1848 2010 , there was a typical significant fluctuation in the 

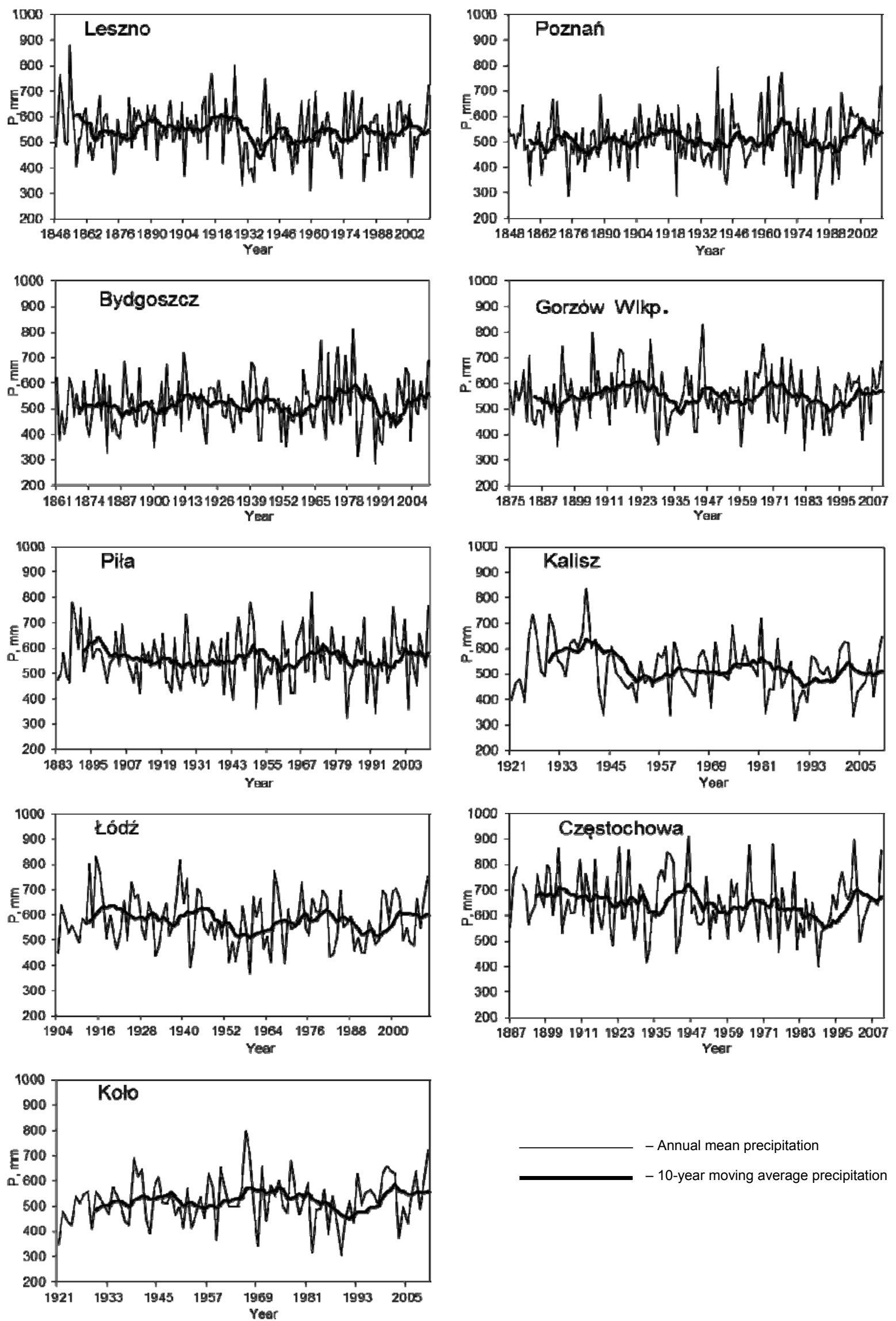

Fig 5. Long term variability of mean annual and 10-year moving average precipitation totals $(\mathrm{mm})$ in Leszno, Poznań, Bydgoszcz, Gorzów Wlkp. Piła, Kalisz, Łódź, Częstochowa and Koło in 1848-2010; source: own study 

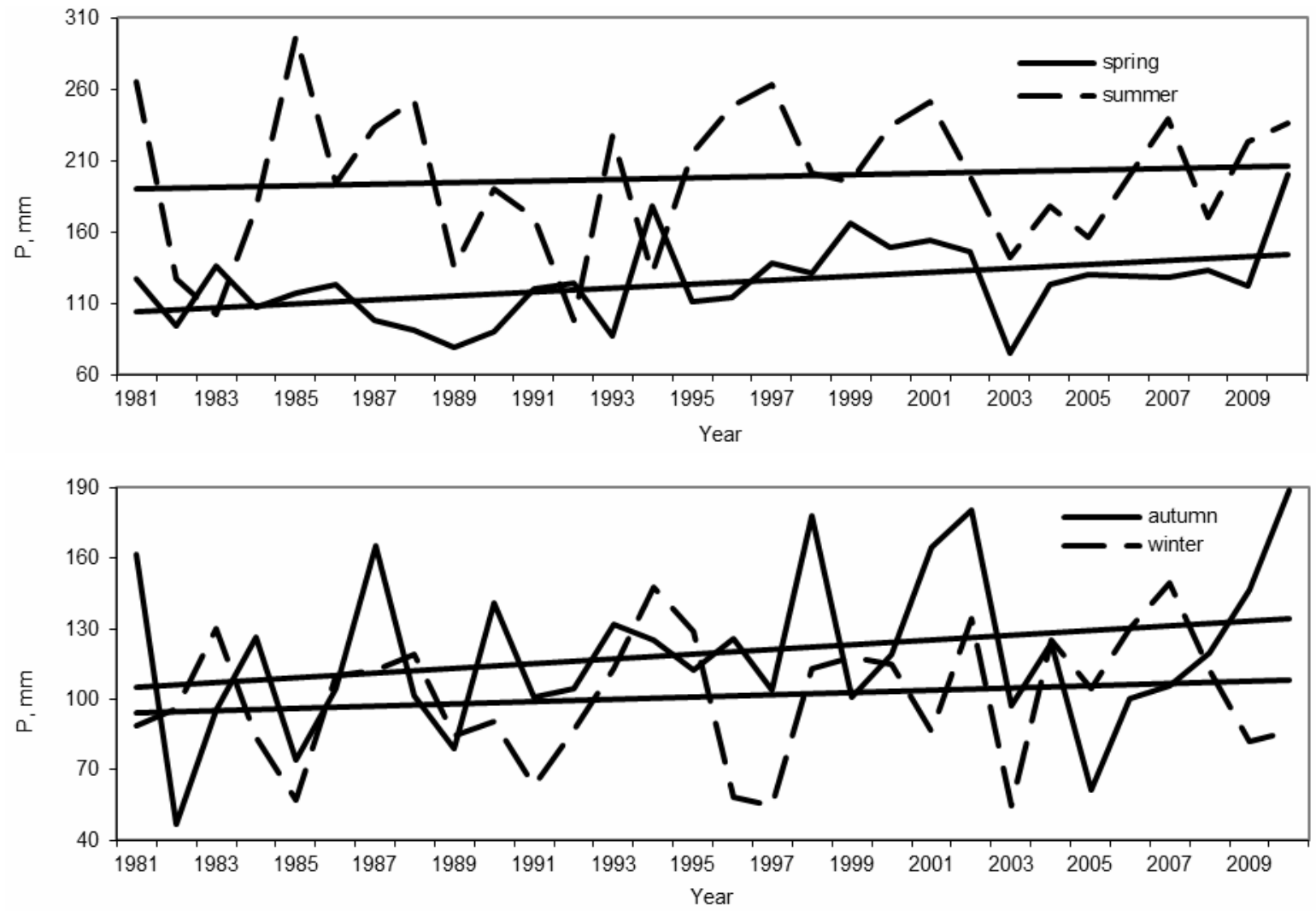

Fig. 6. Variability of precipitation totals in the Warta River basin in four seasons in 1981-2010; source: own study

annual mean precipitation totals and a high variability. In three analysed time-series, the trend of annual precipitation was small and positive, but never statistically significant. In the period 1981-2010, the linear trend of the mean annual precipitation totals in all stations was positive ( $3.5 \mathrm{~mm}$ per decade), but significant only in two out of nine stations. In four seasons, the share of precipitation trend was positive, but significant only in spring (13.6 $\mathrm{mm}$ per decade). A weak increment (14 $\mathrm{mm}$ in 50 years) of annual precipitation totals in 1951-2000 was observed in Poland [DEGIRMENDŽIĆ et al. 2004], Ukraine [NABYVANETS et al. 2011] and Czech Republic [BRÁZDIL et al. 2009]. In Germany for the period 1951-2000 the trend was $+6 \%$ and in 1971-2000 it increased to $+18 \%$ [SCHÖNWIESE, JANOSCHITZ 2008].

Low annual precipitation and increasing air temperature, may lead to a decrease of agricultural production and available water resources. The impact of climate change on agriculture in Europe was analysed in the project "Impact of climate change in Europe" [PESETA 2006-2008]. According to the IPCC SRES scenario A2 and the model HadCM3/HIRHAM, in Poland the change of yields in 2080 in comparison to $1961-1990$ would be only about $\pm 5 \%$. The increase of air temperature causes an increase of potential (not of effective) evaporation and should be reflected in a decrease of water flow in rivers. In 1971-2010 the significant increase in Penman-Monteith reference evapotranspiration in the growing season in Poland (30 mm per 10 years) showed a similar trend to that of air temperature and sunshine hours [ŁABĘDZKI et al. 2014]. However, one must keep in mind that both, the increase of temperature and precipitation occur in the cool half-year accompanied by a significantly decreased evaporation. Soil that is not frozen and rain instead of snow, permit a deeper water percolation into the soil and enrich the groundwater resources. In the period 1896-2010, in Gorzów Wlkp., the mean discharge $\left(210.5 \mathrm{~m}^{3} \mathrm{~s}^{-1}\right)$ in the Warta River showed a positive but insignificant trend $\left(1.11 \mathrm{~m}^{3} \mathrm{~s}^{-1}\right.$ per decade) and a very high variability. The annual mean discharge of 1981-2010 was nearly the same (208.7 $\mathrm{m}^{3} \mathrm{~s}^{-1}$ ) as for the period 1896-2010 [ILNICKI et al. 2014].

\section{CONCLUSIONS}

In the Warta River basin, in the periods 1848 2010 and 1951-2010, the annual mean temperature increased by $0.04^{\circ} \mathrm{C}$ and $0.23^{\circ} \mathrm{C}$ per decade respectively. This was similar that the mean trend measured in the second half of the 20th century in Poland and Germany $\left(0.20^{\circ} \mathrm{C}\right.$ per decade $)$ and in the Northern Hemisphere $\left(0.24^{\circ} \mathrm{C}\right.$ per decade). During the last 30 years (1981-2010) in the Warta River basin, the trend increased to $0.35^{\circ} \mathrm{C}$ per decade. In the Warta River basin the increase of air temperature in the period 1981-2010 was most visible in spring (March-May) and winter (December-February). In the period 18482010, the mean annual precipitation totals (mean 548 $\mathrm{mm}$ ) do not change visible. In the last 30 years an 
increase of precipitation totals mainly occurred in the spring and winter and a decrease in summer. In the period 1896-2010, the mean discharge $\left(209 \mathrm{~m}^{3} \cdot \mathrm{s}^{-1}\right)$ in the Warta River showed a positive, but insignificant trend $\left(1.11 \mathrm{~m}^{3} \cdot \mathrm{s}^{-1}\right.$ per decade $)$. It can be argued therefore that climate changes do not change the long-term mean in the Warta River discharge.

\section{REFERENCES}

BAlling R.C., Vose R.S., Weber G.R. 1998. Analysis of long-term European temperature records 1751-1995. Climate Research. Vol. 10. Iss. 3 p. 193-200. DOI: $10.3354 / \mathrm{cr} 010193$

Brázdil R., Chroma K., Dobrovolný P., Tolasz R. 2009. Climate fluctuations in the Czech Republic during the period 1961-2005. International Journal of Climatology. Vol. 29 p. 223-242. DOI: 10.1002/joc. 1718

Brohan P., Kennedy J.J., Harris I., TetT S.F.B., Jones P.D. 2006. Uncertainty estimates in regional and global observed temperature changes: a new data set from 1850. Journal of Geophysical Research. Vol. 111. Iss. D12 p. 1-26. DOI: 10.1029/2005JD006548

BRYŚ K., BRYŚ T. 2010. Reconstruction of the 217-year (1791-2007) Wrocław air temperature and precipitation series. Bulletin of Geography. Physical Geography Series. $\mathrm{Nr} 3$ p. 121-171.

DEGIRMENDŽIĆ J., KoŻUCHOWSKI K., ŻMUDZKA E. 2004. Changes of air temperature and precipitation in Poland in the period 1951-2000 and their relationship to atmospheric circulation. International Journal of Climatology. Vol. 24. Iss. 3 p. 291-310. DOI: 10.1002/ joc. 1010

Dobrovolný P., Moberg A., BrÁzdil R., Pfister C. et al. 2010. Monthly, seasonal and annual temperature reconstructions for Central Europe derived from documentary evidence and instrumental records since AS 1500. Climatic Change. Vol. 101. Iss. 1 p. 69-107. DOI: 10. 1007/s10584-009-9724-x.

HoHENDORF E. 1966. Opady atmosferyczne w ostatnim stuleciu w Bydgoszczy [Precipitation in the last century in Bydgoszcz]. Bydgoskie Towarzystwo Naukowe. Ser. B. Nr 5(2) p. 169-269.

ILNICKI P., FARAT R., GÓRECKI K., LEWANDOWSKI P. 2012. Mit stepowienia Wielkopolski [Myth of the steppe forming process in the Wielkopolska region from the viewpoint of long investigations of water circulation]. Poznań. UP. ISBN 978-83-7160-672-4 pp. 396.

ILNICKI P., FARAT R., GÓRECKI K., LEWANDOWSKI P. 2014. Impact of climatic change on river discharge in the driest region of Poland. Hydrological Sciences Journal. Vol. 59. Iss. 6 p. 1117-1134. DOI: 10.1080/02626667. 2013.831979.

JONES P.D., LISTER D.H. 2009. The influence of the circulation on surface temperature and precipitation patterns over Europe. Climate of the Past. Vol. 5 p. 259-267.

KLeIn TANK A.M.G., WiJngaARD J.B., KÖNNEN G.B., BÖHM R. et al. 2002. Daily dataset of 20th-century surface air temperature and precipitation series for the European Climate Assessment. International Journal of Climatology. Vol. 22. Iss. 12 p. 1444-1453. DOI: 10.1002/joc. 773.

Klein Tank A.M.G., Können G.P., Selten F.M. 2005. Signals of anthropogenic influence on European warming as seen in the trend patterns of daily temperature variance. International Journal of Climatology. Vol. 25. Iss. 1 p. 1-16. DOI: 10.1002/joc. 1087.

LORENC H. 2000. Studia nad 220-letnią (1779-1998) serią temperatury powietrza $\mathrm{w}$ Warszawie oraz ocena jej wiekowych tendencji [Research of 220-years (17791998) series of air temperature in Warsaw and assessment of centuries tendencies]. Materiały Badawcze IMGW. Ser. Meteorologia. Nr 31. ISSN 0239-6262 pp. 104.

ŁabęDZKi L., BĄK B., SMARZyŃSKa K. 2014. Spatiotemporal variability and trends of Penman-Monteith reference evapotranspiration (FAO-56) in 1971-2010 under climatic conditions of Poland. Polish Journal of Environmental Studies. Vol. 23. No. 6 p. 2083-2091. DOI $10.15244 /$ pjoes/27816.

NABYvANETS J., SERENCO L., ZheleZnyaK M. 2011. Reducing vulnerability to extreme floods and climate change in the Dniester river basin. Pilot project. Core group of the pilot projects on adaptation to climate change in transboundary basins under the UNECE Water Convention [online]. Second meeting Geneva, 23-24 November 2011. [Access 30.09.2015]. Available at: https://www2. un-

ece.org/ehlm/platform/download/attachments/24707075 /Dniester_Nabyvanets.pdf?version=2\&modificationDat $\mathrm{e}=1322568876766$

NYĆKOWIAK J., LEŚNY J., OLEJNIK J. 2014. Change in meteorological conditions in a Polish city, 1848-2009. Polish Journal of Environmental Studies. Vol. 23. No. 1 p. 149-155.

PESETA project 2008. Impacts of climate change in Europe. Final results Reports. JRC European Commission IPTS. Project: Impacts of climate change on agriculture [online]. [Access 30.09.2015]. Available at: http:// peseta.jrc.ec.europa.eu/results.html

RADZIEJEWSKI M., KUNDZEWICZ Z.W. 2000. Hydrospectsoftware for detecting changes in hydrological data. In: Detecting trend and other changes in hydrological data, 151-152 (appendix 2). Eds. Z.W. Kundzewicz, A. Robson. World Climate Programme - Water, WCDMP-45, WMO/TD No. 1013 Geneva.

RADZIEJEWSKI M., KunDZEWICZ Z.W. 2004. Development, use and application of the HYDROSPECT data analysis system for the detection of changes in hydrological time series for use in WCP-Water and National Hydrological Services WCASP-65, Hydrospect, ver. 2.0. User's Manual, WMO Geneva.

Rohde R., Muller R.A., Jacobsen R., Muller E., PerlMUtTer, Rosenfeld A., Wurtele J., GroOM D. WiCKHAM C. 2013. A new estimate of the average earth surface land temperature spanning 1753 to 2011 . Geoinfor Geostat: An overview 1:1. DOI: 10.4172/2327-4581. 1000101

Rutgersson A., JaAgus J., Schenk F., Stendel M. 2014. Observed changes and variability of atmospheric parameters in the Baltic Sea region during the last 200 years. Climate Research. Vol. 61 p. 177-190. DOI: $10.3354 / \mathrm{cr} 01244$

SCHERRER S.C., APPENZeller C., Lininger M.A., SCHÄr C. 2005. European temperature distribution changes in observations and climate change scenarios. Geophysical Research Letters. Vol. 32. Iss. 19 p. 1-5. DOI: 10.1029/ 2005 GL024108.

SCHÖNWIESE CH.D., JANOSCHITZ R. 2008. Klimatrendatlas Deutschland 1901-2000 [The climate trend atlas Germany 1901-2000] [online]. Berichte d. Inst. Atmosph. Umwelt, Univ. Frankfurt/M. Nr 4 pp. 63. [Access 
30.09.2015]. Available at: http://www.uni-frankfurt.de/ 45447808/Inst_Ber_421.pdf

SMOSARSKI W. 1925. Temperatura i opady w Wielkopolsce [Temperature and precipitation in the Wielkopolska region]. Prace Komisji Matematyczno-Przyrodniczej PTPN. Ser. A. Nr 2 p. 75-176.

Suryavavanshi S., Pandey A., Chaube U.Ch., Joshi N. 2014. Long-term historic changes in climatic variables of Betwa Basin, India. Theoretical and Applied Climatology. Vol. 117 (3-4) p. 403-418. DOI: 10.1007/ s00704-013-1013-y

Trenberth K.E., Jones P.D., Ambenje P., Bojariu R. et al. 2007. Observations: Surface and atmospheric climate change. In: The physical science basis. Eds. S. Solomon, D. Qin, M. Manning et al. Contribution of Working Group I to the Fourth Assessment Report of the IPCC, Climate change [online]. [Access 30.09.2015]. Available at: https://www.ipcc-wg1.unibe.ch/ publications/wg1-ar4/wg1-ar4.html

Wibig J., FortUNIAK K., KŁYSIK K. 2004. Rekonstrukcja serii temperatury powietrza w Łodzi z okresu 1903-
2000 [The reconstruction of the air temperature record in Łódź for the period 1903-2003]. Acta Geographica Lodziensia. Nr 89. Łódź. Wyd. Łódzkie Tow. Nauk. p. 19-33.

WiBig J., RzePA M. 2007. Rekonstrukcja serii dobowych sum opadu w Łodzi w latach 1904-2000. W: 200 lat regularnych pomiarów i obserwacji meteorologicznych w Gdańsku [Reconstruction of a series of daily precipitation totals in Łódź in the years 1904-2000]. Eds. M. Miętus, J. Filipiak, A. Wyszkowski. Ser. Monografie IMGW. Warszawa p. 92-99.

Zhang Q., Peng J., Xu C.Y, Singh V.P. 2014. Spatiotemporal variations of precipitation regimes across Yangtze River Basin, China. Theoretical and Applied Climatology. Vol. 115. Iss. 3-4 p. 703-712. DOI: 10.1007/ s00704-013-0916-y

ŻMUDZKA E. 2004. Tło klimatyczne produkcji rolniczej w Polsce w drugiej połowie XX wieku [The climatic background of the agricultural production in Poland in the second half of 20th century]. Acta Agrophysica. Vol. 3. Iss. 2 p. $399-408$.

\section{Piotr ILNICKI, Ryszard FARAT, Krzysztof GÓRECKI, Piotr LEWANDOWSKI}

\section{Wieloletnia zmienność temperatury powietrza i opadów atmosferycznych w zlewni rzeki Warty}

\section{STRESZCZENIE}

Słowa kluczowe: analiza trendów, opady atmosferyczne, Polska, temperatura powietrza, zlewnia rzeki Warty

W zlewni rzeki Warty, położonej w rejonie o najniższych w Polsce opadach atmosferycznych, analizowano zmienność średnich rocznych wartości temperatury i sum opadów w latach 1848-2010, 1951-2010 i 1981-2010. W tym celu wykorzystano dane z dziewięciu stacji meteorologicznych dysponujących najdłuższymi seriami pomiarowymi. Głównym celem tych badań było zebranie wieloletnich danych dotyczących temperatury powietrza i sumy opadów atmosferycznych w zlewni Warty i statystyczna analiza ich zmienności. Temperatura powietrza wzrastała w tej zlewni w podobny sposób, jak w sąsiednich krajach. W ostatnich 30 latach zaobserwowano nasilenie się tego trendu. Opady atmosferyczne w całym badanym okresie nieco wzrosły w północnej i zmalały w południowej części zlewni, ale średnia roczna suma opadów w całej zlewni nie zmieniła się istotnie. W latach 1981-2010 roczna suma opadów nieco wzrastała zimą i wiosną oraz malała latem. W średnich rocznych przepływach Warty negatywny wpływ tych zmian nie był widoczny. 